\title{
Der Weiher
}

Ruhig, still fliesst es in dem Teich, ungeahnt von dem nachfolgenden Sturz aus künstlicher Höhe.

Tag und Nacht blickt der Weiher sanft himmelwärts, kaum empört über Schläge des Hagels, getrübt lediglich durch den wütenden Bach.

Willkommen sind das Laub, auch das Reisig, die Nacht, das Licht, der Wind und der Regen, der Nebel. auch der Frost.

Im Weiher leben

Fische, Enten, der Schwan

und der Schatten

des Kirschbaums,

dein Gesicht,

der Himmel samt der Sonne, den Sternen und dem Mond.

Der Weiher lebt

mit dem Wind,

durch die Wellen

und der Fische Atem.

geflügelte Enten

fliegen davon,

geschnitten ist

an den Schwungfedern

der Schwan.

Die Urheimat,

oder Heimat der Urahnen,

Quelle des Lebens

gleitet, rollt,

es wird geleitet,

geformt durch den Kanal

unter den rollenden Autos,

unter der Strasse

vor dem Sturz

in das nächste Becken.
Im Weiher haust

die Rückkehr

für die dazu Berufenen! und sie liebäugelt, ruft, lockt an und versucht auch Selbstentflohene, ja gar nur im Schein Verlorene.

Der Weiher im Gesang mit dem Wind, den Singvögeln, begleitet vom Solo der Kuh, vom Takt der Kirchenglocken. Und ab und zu im Mondschein erklingt aus dem Flecken im gerodeten Wald das Gebet einer Eule für die Säge, für die Axt. Und der Wind tobt irrend herum.

Ebbe und Flut, nicht im Sog der Sonne, nicht die Anziehung des Mondes, die Berührung, die Interferenz der Wolken, der Blitz, der Donner, die fallenden Samen im Strom schüren den Bach, schwängern die Erde, schwellen den Weiher.

Der Weiher wächst nach Abfluss weisser Glasur, nach Aufprall der dichten Wolken, vor Ankunft der Zugvögel, dann sprengt er den Rahmen. überflutet das Ufer ohne Rücksicht auf die Enten, auf den Schwan, ohne Respekt vor dem Zaun.
Der Seufzer der Fische

Hinter den engmaschigen Gittern, nach vergeblichen Sprüngen in den Bach zu gelangen.

Aktuell wieder «Sein oder Nichtsein!», die Plage des Lebens

hinnehmen, ringen um die Luft? Das Elixier fliesst dahin in Flut

und von Angeln wimmelt es hinter dem Gitter im Trüben!

Von einer Schale in eine andere trabt das Wasser unterwegs zum Fluss.

Die Fische machen halt auf Gebot des Gitters und vergiessen keine Tränen. Das Klagelied nimmt das Wasser ins Meer auf der ewigen Laufbahn im Kreis, getrieben vom Feuer in den unendlichen Kampf der Widersprüche des Daseins.

Ruhig, umzäunt von Kiesel und Latten fliesst das Leben in dem Weiher.Am Ufer steht ein Mann ratlos im Fluss und sucht den Sinn des Lebens im Rauschen der Gewässer. 